\title{
A SUGGESTION ON THE NEGRO PROBLEM
}

\author{
CHARLOTTE PERKINS GILMAN \\ New York City, N. Y.
}

Transfusion of blood is a simple matter compared with the transfusion of civilization; yet that is precisely what is going on between us and the negro race.

They were forcibly extradited from a distant country, from a status far lower than our own; and we for our own purposes gave them a compulsory introduction into our economic group, and made them working factors in our society.

The results proved increasingly disadvantageous. The first arbitrary relation has been laid aside, but the sociological problem is not solved because one answer is seen to be wrong.

Admitting that in a certain number of cases the negro has developed an ability to enter upon our plane of business life, and further admitting, most cheerfully, that this proves the ultimate capacity of the race to do so; there remains the practical problem of how to accelerate this process.

We have to consider the unavoidable presence of a large body of aliens, of a race widely dissimilar and in many respects inferior, whose present status is to us a social injury. If we had left them alone in their own country this dissimilarity and inferiority would be, so to speak, none of our business.

There are other races, similarly distinguished, whose special standing in racial evolution does not embarrass us; but in this case it does. These were imported, much against their wills, for our supposed advantage; and as their inferiority was the very condition of our advantage, making possible their exploitation, no complaint was then made of it.

The laws of economic evolution proved that this supposed advantage was counterbalanced by such heavy disadvantages that it did more harm than good; and with many blunders and much suffering and loss we put an end to the economic relation 
in which the negro had been held, and set him free; freean alien race, in a foreign land; under social, economic, political, and religious conditions to which he was by heredity a stranger. By consummate mishandling of the crucial period of change, the break in the relations between blacks and whites became a gulf, and has since widened. We now have an immense area of country in which are found two races, of different degrees of social advancement, living side by side, only partially serviceable to one another, and in many ways antagonistic.

On the field of economic competition into which the negro was so suddenly thrown he does not, as a whole, in fifty years, show equality with us-which is not remarkable. That so many negroes, in this brief time, have made such great progress, is the element not only of hope, but of security in facing our problem. The problem is this:

Given: in the same country, Race A, progressed in social evolution, say, to Status Io; and Race B, progressed in social evolution, say, to Status 4 .

Given: That Race A outnumbers Race B as ten to one.

Given: That Race B was forcibly imported by Race A, and cannot be deported.

Given: That Race B, in its present condition, does not develop fast enough to suit Race A.

Question: How can Race A best and most quickly promote the development of Race $B$ ?

This problem need not be confused by the element of injury and offense. It is true that Race $B$ in many ways retards the progress of Race A, and grievously offends against it; but it is also true that Race A was the original offender, and has a list of injuries to Race B, greatly outnumbering the counter list. It is also true that both races have served each other in many ways. These points may be laid aside. They arouse our feelings and do not clear our thoughts.

The problem - the question of conduct-the pressing practical issue-is, What can we do to promote the development of the backward race so that it may become an advantageous element in the community? This is not a question of "equality" in 
any sense. Society is an organic relation, it is not composed of constituents all alike and equally developed, but most diverse and unequal. It is quite possible to have in a society members far inferior to other members, but yet essential to the life of the whole.

A man would rather lose all his ten toes than his two eyes; and both feet than his eyes and ears. Our special senses are far "superior" to our meat and bones; yet it is quite essential to the body's life that even its least important parts be healthy.

If the negro population can become entirely self-supporting and well behaved it ceases to be a "problem" and a menace. If it becomes more than self-supporting, contributing its quota to the general good, then it will be a valuable part of the body politic, an advantage to us all. The fact that so many negroes have reached this position is the proof that social evolution works more rapidly than the previous processes of natural selection. The African race, with the advantage of contact with our more advanced stage of evolution, has made more progress in a few generations than any other race has ever done in the same time, except the Japanese. That splendid instance of this process of self-conscious social evolution shows the irresistible power of direct transference of institutions, and their result. Our own general history, with its swift, resistless Americanization of all kinds of foreigners, shows the same thing. The evolution of society, while based on natural conditions and forces, has long since reached the stage where it is directly promoted by society's own efforts. From the foreigner of every sort the American is made by sharing with him the advantages of our institutionseven by compelling him to partake of that advantage. This brings us again to our direct question: How can we best promote the civilization of the negro?

$\mathrm{He}$ is here; we can't get rid of him; it is all our fault; he does not suit us as he is; what can we do to improve him?

At last the suggestion: Let each sovereign state carefully organize in every county and township an enlisted body of all negroes below a certain grade of citizenship. Those above it - the decent, self-supporting, progressive negroes-form no 
problem and call for nothing but congratulation. But the whole body of negroes who do not progress, who are not self-supporting, who are degenerating into an increasing percentage of social burdens or actual criminals, should be taken hold of by the state.

This proposed organization is not enslavement, but enlistment. The new army should have its uniforms, its decorations, its titles, its careful system of grading, its music and banners and impressive ceremonies. It is no dishonor but an honorable employment from the first, and the rapid means of advancement. Men, women, and children, all should belong to it-all, that is, below the grade of efficiency which needs no care. For the children-this is the vital base of the matter-a system of education, the best we have, should guarantee the fullest development possible to each; from the carefully appointed nursery and kindergarten up to the trade school fitting the boy or girl for life; or, if special capacity be shown, for higher education.

This at once stops the lowering process-it leaves the state only the existing crop of low efficients to handle, and insures the higher efficiency of the next generation. Those old enough to work should be employed as follows : enough should be placed on farms to provide for the entire body. These farms should be model farms, under the best management, furnishing experiment stations, and bases for agricultural instruction, as well as the food for the whole army and all its officials; and where cotton and such products were raised, they would be a further source of income. As a large percentage of the negro population is best suited to agricultural labor, and this would prove a very important working base for the institution. By modern methods of advanced agriculture the land would be improved; the best results obtained from it, and the laborers continually taught their business. The surrounding country would be benefited by these stations.

Another large number, in mills and shops belonging to the undertaking, would make clothing, uniforms, etc., for them all; and another detachment would assist in the necessary building.

All these are but the internal functions of the new body; its direct service to society would be in meeting the crying need of 
the whole South for better roads, harbors, river banks, and the general development of the country. Construction trains, carrying bands of the new workmen, officers, and men, with their families, with work for the women and teaching for the children, would carry the laborer along the roads he made, and improve the country at tremendous speed.

With proper food, suitable hours of work, rest, and amusement; without the strain of personal initiative and responsibility to which so many have proved unequal, a great amount of productive labor would be thus brought to the service of the community. As fast as any individuals proved themselves capable of working on their own initiative they would be graduated with honor. This institution should be compulsory at the bottom, perfectly free at the top.

Each company would have its clerk, each individual would have his separate account as soon as his labor passed the amount necessary for the support of the institution; and, when above that amount, a wage fund should accumulate credited to each, furnishing a small capital to start with when graduated. Many who would not perhaps prove capable of entire personal responsibility, could be organized in small post-graduate groups of farms or shops, and so remain until they went on to higher efforts; or perhaps came back into the army.

What this amounts to is simply state organization of the negro, under conditions wholly to his advantage, and therefore to ours. Some persons, hasty in speech, will now be asking "Who is to pay for all this?" To which the answer is "The same who paid for all the comforts and luxuries of the South in earlier years - the working negro.

Applied labor is wealth.

The unorganized negro does not seem capable in many instances of utilizing his own forces. This organization provides the machinery best to elicit and apply the working force of this great mass of people: and would do so at no loss whatever. If any man, privately, were allowed to govern the labor of, say, a thousand negroes, to his own advantage, he would not be asking "who pays for it?" 
The funds necessary to start an undertaking of this sort would, in the first instance, have to be advanced by the several communities interested, but would promptly be returned, and thereafter the organization would be no expense to the community but would pay for itself. Meanwhile the applied labor would result in improvements to the country of endless value, and the improvement in the negroes themselves would add steadily to their value as constituents of the body politic.

A certain percentage of degenerates and criminals would have to be segregated and cared for as they are now, only far more wisely. But the saving to the state in cutting off the supply of these degenerates would go far to establish the economy of the proposition.

Here is at present an undeveloped country and an undeveloped race. Here is potential labor that will not apply itself, and the need for labor unmet. This plan brings the labor to the place where it is wanted, and benefits the laborer in the process. There should be nothing offensive in the whole undertaking. Compulsory education we demand for all in many states; this would enforce it more thoroughly, that is all.

The enlistment would be compulsory, but so is enlistment in the army in highly civilized lands, and that is not held dishonorable. To be drafted to a field of labor that shall benefit his own race and the whole community, need not be considered a wrong to any negro. The whole system should involve fullest understanding of the special characteristics of the negro; should be full of light and color; of rhythm and music; of careful organization and honorable recognition. It should furnish good physical training and as much education as each individual can take.

Every negro graduated would be better fitted to take his place in the community. Every negro unable to graduate would remain under wise supervision, would be really self-supporting, and also help in the great work of raising his people.

Then someone will ask "What will you do when the roads and harbors are all done-when the rough work is exhausted 
and the country all properly developed?" By the time that happy end is accomplished there will probably be no negro problem.

"But in the meantime," says the questioner, "How are you going to be sure this great undertaking will be managed wisely, honestly, efficiently? Where are you going to get your superior teachers, your managers and superintendents? What is going to prevent the establishment of an immense system of peonage, of state slavery, of enormous profits wrung from these compulsory enlistments? Of "Army scandals" beside which those of Europe will be as nothing?"

This is a somewhat deterrent suggestion.

If Race A, in Status Io, cannot so behave itself as thus to elevate and improve Race B, in Status 4 , it is somewhat of a reflection upon its superiority.

If we, with all our boasted advancement, are incapable of administering a plan of such visible usefulness to both races, of such patent economy and permanent benefit, then we need some scheme of race betterment ourselves. But it does not call for any superhuman virtue.

By the same methods in which a state or county arbitrarily provides for its poor, its defectives, or for the education of its children; so it could now bestir itself to provide for this large class of comparatively backward citizens. If the arrangement were made very clear and visibly attractive, and volunteers were called for, with some special honor and recognition for them, it is quite possible that numbers would enlist of their own accord. It might be called the bureau of Labor and Education, or of Labor and Improvement, and arranged on a military basis, with. its construction camps, its base of supplies Nos. I, 2, 3, etc.; it would form a continuous school for all ages, slowly shrinking and withdrawing as the younger generation of colored people showed their ability for voluntary co-operation or entirely individual effort.

Especial care should of course be given to the management, that it be "kept out of politics," and that the finances of the institution be continually open to the public, that full annual 
reports be printed, and that every means be taken to ensure a fair and just administration.

A training-school for domestice service might be part of each stationary base; and individuals could be sent from this on probation as it were-perfectly free to remain out in satisfactory home service, or to improve their condition as they were able. In case of unsatisfactory service they should be reinlisted-and try some other form of labor.

A plan of organized labor that would make all negroes self supporting; a plan of education that would make the whole race rise in social evolution; a plan of local development that would add millions to the value of the southern land, and all within the independent power of each state-surely such a plan is worth considering. 